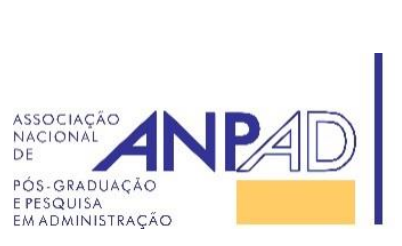

Disponível em

http://www.anpad.org.br/rac

RAC, Rio de Janeiro, v. 22, n. 3, art. 6, pp. 424-442, maio/junho, 2018,

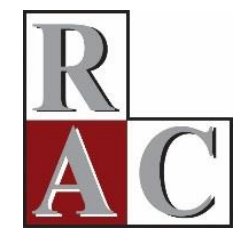

\title{
Sustainable Competitive Advantage Needs Green Human Resource Practices: A Framework for Environmental Management
}

Universidade Federal de Juiz de Fora, Faculdade de Administração e Ciências Contábeis, Juiz de Fora, MG, Brasil $^{1}$ Universidade Federal de Minas Gerais, Departamento de Ciências Administrativas, Belo Horizonte, MG, Brasil² 


\title{
Resumo
}

O objetivo deste ensaio teórico é analisar o papel da gestão de recursos humanos (RH) para alcançar a vantagem competitiva sustentável (VCS) nas organizações, por meio da perspectiva da Visão Baseada em Recursos Naturais (VBRN). Foi realizada uma pesquisa bibliográfica de natureza exploratório-descritiva. Primeiro foram apresentadas definições-chave para identificar a VCS como sustentabilidade, desenvolvimento sustentável e sustentabilidade organizacional. Um quadro teórico foi desenvolvido integrando práticas de RH com estratégias da VBRN (prevenção de poluição, administração de produtos e desenvolvimento sustentável) para alcançar a VCS. A principal contribuição deste estudo é oferecer uma síntese integrativa sobre práticas de RH e estratégias da VBRN. Este artigo também agrega valor aos gerentes, apresentando formas de implementar o gerenciamento de RH para a realização da sustentabilidade organizacional.

Palavras-chave: visão baseada em recursos naturais; gestão de recursos humanos; sustentabilidade; vantagem competitiva sustentável.

\begin{abstract}
The aim of this theoretical essay is to analyze the role of human resource (HR) management to achieve organizational sustainable competitive advantage (SCA), through the Natural Resource Based View (NRBV) perspective. We performed an exploratory-descriptive bibliographic research. We first provide key definitions to identify SCA, such as sustainability, sustainable development, and organizational sustainability. We then developed a theoretical framework integrating HR practices with NRBV strategies (pollution prevention, product stewardship, and sustainable development) in order to achieve SCA. As results, a set of propositions regarding HR management and sustainability are offered to be empirically analyzed in future research. The major contribution of this study is to offer an integrative framework of HR practices and NRBV strategies. This paper also adds value to managers by presenting ways to implement HR management for organizational sustainability achievement.
\end{abstract}

Key words: natural resource based view; human resource management; sustainability; sustainable competitive advantage. 


\section{Introduction}

The Conference on the Changing Atmosphere held in Canada in 1988 raised awareness about environmental responsibility, leading the Intergovernmental Panel on Climate Change (IPPCC) to present its first assessment report in 1990. Later, in 1992, the ECO-92 Convention on Climate Change held in Rio de Janeiro created the Agenda 21. This agenda gives direction for governments to implement local and nationwide goals to create sustainable development. The ECO-92 also fostered the negotiations between developed countries about the Kyoto Protocol held in Japan in 1997. The Kyoto Protocol only entered into force in 2005 due to the variety of interests and the lack of agreement between the parties. The 55 industrialized countries that signed the agreement committed to reduce greenhouse gas emissions and implement flexibility mechanisms, such as joint implementation, clean development mechanisms, and international emissions trading. In 2013 the agreement was ratified by 191 countries, representing over 60\% of emissions (United Nations Framework Convention on Climate Change [UNFCCC], 2014).

All this movement is directly related to the scarcity of natural resources, initiated by the Industrial Revolution. The exponential growth of consumption and production represents the industrial philosophy of the Classical Administration era, in which natural resources were taken for granted (Cano, 2017). Governments created production and consumption policies to encourage economic development based only on an economic perspective, without taking into account environmental concerns. Even nowadays such policies are implemented, especially in developing countries. In Brazil, for example, a set of policies was created to encourage the production of high-quality coffee in 2015 and rubber in 2016. The government also reduced taxes on automobiles and home appliance products to foster consumption. The National Development Bank Economic and Social (BNDES) was used to subsidize the interest rates (Câmara dos Deputados, 2015, 2016).

Academic studies focused on the effects of pollution on climate change and the indiscriminate use of natural resources have gained considerable attention since the end of the 1990s. In business, these studies have progressed discussions toward the environmental responsibility of companies, governments, and organized sectors of the society (Golicic \& Smith, 2013; Shi, Koh, Baldwin, \& Cucchiella, 2012; Willerding, Silveira, Berchin, Lapolli, \& Guerra, 2016).

In 1995, Hart developed the Natural Resource Based View (NRBV), which is based on the Resource Based View (RBV) theory developed by Barney (1991). The NRBV theory draws attention to environmental practices regarding sustainable competitive advantage. The NRBV proposes that sustainable competitive advantage is achieved when an enterprise's resources which are valuable, rare, inimitable, and non-substitutable are related to specific strategic capabilities, such as pollution prevention, product stewardship and sustainable development (Hart, 1995). In addition, Hart and Dowell (2011) developed the Clean Technology and Base of Pyramid (BoP) to facilitate the implementation and measurement of the three environmental strategies. To develop these strategies, employees must get involved, and organizations must emphasize that environmental concerns are taken as a strategic value. Therefore, human resource (HR) policies and practices are critical to organizations in order to achieve sustainable competitive advantage, because organizations can incorporate sustainable habits into their routine and processes through HR policies and practices (Dubois \& Dubois, 2012). These habits may be institutionalized into organizational culture if organizations promote changes in employees' values and behaviors, for example, by developing HR systems (hiring and promoting) based on sustainable values (Aragón-Correa \& Sharma, 2003; Borges \& Michalisin, 2009; Chan, 2005; Hart, \& Sharma, 2004).

Human resource management presents itself as a possible way to achieve a sustainable competitive advantage. Dumont, Shen, and Deng (2017) find that green HR management can affect employee green behavior depending on the social and psychological processes. HR management must be strategically aligned with the sustainable perspective the organization intends to develop and maintain. However, despite the growing body of research linking HR management and sustainable competitive advantage, Buller and McEvory (2016) point out that the literature is still evolving. Kaufman (2015) posits that the relationship between HRM and RBV is well known in the literature, 
considering about 25 years of research. Nonetheless, according to the author, it lacks well-grounded constructs, as HR management needs to shift focus and add value creation to organizations. Finally, Delery and Roumpi (2017) add that researchers need to overcome the tendency to directly relate HR practices to organizational performance. They claim that HR practices lead to sustainable competitive advantage through the context (trajectory over time), ambiguity (competitors do not think a specific HR practice is important), organizational factors (culture and structure), and social system (employees' abilities and skills).

In this sense, this theoretical essay, grounded in the natural resource based view approach (NRBV), analyzes the role HR management has in helping organizations achieve sustainable competitive advantage. Therefore, the objective of this paper is to present a theoretical framework by analyzing the role of human resource management as a feasible path to help organizations achieve a sustainable competitive advantage, through the natural resource based view perspective.

We performed a bibliographic research to provide an integrative synthesis of the literature regarding NRBV and human resource management. Therefore, this is an exploratory-descriptive bibliographic research, since a consistent analysis of the literature was made to explain and justify an integrative perspective (Lima \& Mioto, 2007). The universe of this research is delimited by four criteria: (a) Theme - the initial search was based on Hart's (1995) paper on NRBV, since we looked for every research based on NRBV, following with a search using the keywords organizational sustainability, and sustainable competitive advantage and HR management; (b) Language - we searched for research in Portuguese and English languages; (c) Sources - in the major databases, such as EBSCO, JSTOR, and Google Scholar, the search focused on peer reviewed journals, books, and some dissertations; and, (d) Chronological parameter - the initial search was limited to the last 5 years, then in the last 10 years, and finally, some exceptions were made to include well-known authors and relevant publications. As a result, we developed a theoretical framework integrating HR practices with the NRBV strategiespollution prevention, product stewardship, and sustainable development-in order to achieve a sustainable competitive advantage.

This essay intends to contribute to existing literature by meeting the call by Kaufman (2015) for creating value to organizations. Value creation is related to offering meaningful organizational differentiation to employees, consumers, and society by showing how environmental HR practices are related to sustainable competitive advantage. In this sense, not only do organizations achieve positive outcomes, such as market recognition, but also employees get to keep involved as result of high HR management work practices. Finally, this study addresses Delery and Roumpi's (2017) claim for alternative ways to link HR management and sustainable competitive advantage.

First, this essay presents the concepts of sustainability, sustainable development, and organizational sustainability. Second, we discuss how HR management literature is related to sustainable competitive advantage, grounded in the natural resource based view perspective. Third, we present an integrative theoretical framework developed as result of the literature review. The framework proposes that sustainable competitive advantage can be achieved when organizations develop HR practices designed to address the three NRBV strategies - pollution prevention, product stewardship, and sustainable development. Finally, the conclusion section offers a final discussion and suggestions for future research.

\section{Literature Review}

\section{Organizational sustainability}

The concepts of sustainability and sustainable development are not clearly defined in the literature, since several concepts may be found depending on the contextual reference (Lélé, 1991; Mebratu, 1998). In a historical perspective, Mebratu (1998) affirms that sustainability encompasses the 
idea of living in harmony with nature and society. In management, one of the sustainability concepts refers to the Triple Bottom Line (TBL) developed by Elkington (1994). This author considers that sustainability is something to be achieved through financial, social and environmental dimensions (Elkington, 1994; Gabriele et al., 2012).

The financial dimension refers to meeting the needs of individuals through the use and transformation of scarce resources into products and services. The aim of this dimension is to provide an equitable distribution of wealth between rich and poor countries. However, the big question posed is: How to reduce inequity among nations if most financial capital is controlled by large corporations? The challenge is to break this concentration of capital by encouraging regional companies, which have a great impact on the local community (Dias, 2015).

The social dimension addresses cultural issues and individuals' living conditions in relation to their beliefs, values, and characteristics. A world in which social needs are met is a world where poverty and hunger are eradicated; everyone has access to a healthy life; governments provide basic services; gender equality is a reality; and inequalities between countries are overcome or, at least, reduced considerably (Dias, 2015).

The environmental dimension focuses on the limitation and scarcity of natural resources. The environment and its systems are the basis of sustainable life. So, careful observation, consideration, and respect for the cycle of life are necessary to avoid exploitation overcoming the renewal of resources. In addition, organizations need to draw attention and stop misusing natural resources, mitigate pollution, and reduce carbon footprint. The three dimensions should be considered together in a holistic approach because sustainable issues cannot be solved in isolation (Dias, 2015). The purpose of the TBL model is to measure the company's financial, social and environmental performance. The results of evaluations of these dimensions tend to reflect the values that the organization is building or destroying.

Therefore, according to the literature, sustainability can be defined as the whole that will be achieved through sustainable development (Dias, 2015; Elkington, 1994; Sartori, Latrônico, \& Campos, 2014). That is, sustainability is only achieved in full if the entire development process is sustainable globally.

The most widely used concept of sustainable development was established in 1987 by the United Nations World Commission on Environment and Development (WCED), also known as the Brundtland Commission. WCED presented the document Our Common Future. This document defined sustainable development as what meets the needs of the present without compromising the ability of future generations to meet their future needs (Munck \& Borim-de-Souza, 2011; WCED, 1987). This concept was widely disseminated and supported by several institutions, companies, and governments (Munck \& Borim-de-Souza, 2011).

In business literature, organizational sustainability (SO) can be considered an important part of sustainable development to achieve global sustainability. In order to achieve organizational sustainability, it is necessary that companies, in general, review their processes, policies, organizational objectives, and strategy towards environmental concerns. This idea of organizational sustainability leads to the Triple Bottom Line model (Elkington, 1994), in which the interdependence and inter-relational nature of the environmental, social, and economic dimensions is a feasible way to achieve sustainability (Borim-de-Souza, Balbinoto, Travis, Munck, \& Takahashi, 2015).

There are other models that discuss and represent organizational sustainability (Munck, Bansi, \& Galleli, 2016). For example, Marrewijk and Werre (2003) added the pillar of organizational values to Elkington's three pillars (1994). However, the concept of organizational sustainability of the TBL model - based on financial, environmental, and social dimensions - seems to be the most adequate for developing a framework integrating NRBV strategies and HR practices towards sustainable competitive advantage. 


\section{HR management and sustainable competitive advantage}

One of the purposes of human resources management is to translate organizational values and objectives into HR policies and practices. From an environmental perspective, Borges and Michalisin (2009) state that human resource practices must be created and directed toward a NRBV approach for organizations to obtain a sustainable competitive advantage. Specifically, environmental concerns may be included in recruitment and selection processes (Dubois \& Dubois, 2012; Parkes \& Borland, 2012). Parkes and Borland (2012) also suggest that HR systems can carry out ways of adding environmental issues for company sustainability through rewards and training. It is possible to transform HR management systems to meet organizations' sustainable strategies and goals (Ulrich, 1998).

Competitive advantage is created on the basis of social legitimacy (Hart, 1995). The tacit competence acquired through the involvement of employees to prevent pollution is a resource that cannot be acquired or imitated by competitors (Hart, 1995; Pee \& Kankanhalli, 2015). Product stewardship is related to sustainable competitive advantage because it helps to accumulate complex resources, such as easy the flow of communication across functions, departments, and organizational boundaries. Hart and Dowell (2011) add that sustainable development supports sustainable competitive advantage by stimulating and maintaining a collective sense of the social environment in organizations (Hart \& Dowell, 2011).

The NRBV approach supports that it is possible to accumulate rare, inimitable, and nonsubstitutable resources as organizations develop a shared vision of the future focused on new technologies, invest in new competencies, and employ dynamic capacities. Environmental strategies are interconnected in a relationship of dependence in which pollution prevention needs to be done initially, so that product stewardship can be developed, and, ultimately, sustainable development can take place (Hart, 1995; Hart \& Dowell, 2011).

Several empirical research have investigated the effect of the NRBV on financial performance. Menguc and Ozanne (2005) found that environmental practices can be profitable in terms of rates and market share. In a study of foreign investment in China, Chan (2005) confirmed that a firm's specific resources directly influence its capacity, and capacity directly influences the adoption of environmental strategies and financial performance. Michalisin and Stinchfield (2010) found that firms with proactive strategies related to climate change achieve significantly higher rates of performance than those that are less proactive. On the other hand, Christmann (2000) did not find a significant relationship between the implementation of practices related to pollution prevention and cost advantage.

The first step to organizations developing environmental strategies is to analyze specific resources that are important for implementing proactive dynamic environmental strategies (Aragón-Correa \& Sharma, 2003). Environmental strategy tends to be effective when the company acquires green skills (Walls, Phan, \& Berrone, 2011). Therefore, it is necessary to insert the role of employees into the equation, so that the adoption of environmental strategies may be effective (Chan, 2005).

The acquisition of green technologies by themselves is not a sufficient condition to guarantee sustainable competitive advantage (Hart, 1995). Organizations need to rethink their culture to add the sustainable perspective. In this sense, Borges and Michalisin (2009) argument that green organizational culture begins with strategic HR management, which reformulates its practices to add environmental concerns. Concern about environmental issues must be embedded in the organizational atmosphere, targeting employees' goals and actions (Dubois \& Dubois, 2012). Hart and Dowell (2011) point out that it is possible to develop breakthrough strategies inside companies to solve social and environmental problems. A simple reduction of the impacts associated with companies' operations footprints is not enough to solve environmental sustainability problems. The whole company needs to embrace a certain level of social responsibility starting from inside, but not limited to this alone.

HR management becomes a business partner when it considers four areas of action (roles), which are: being a strategic partner, being an administrative specialist, advocating for employees, and being a change agent (Ulrich, 1998). The future of HR management is to focus on global management, 
organizational capabilities, cultural change, and intellectual capital. For a human resource department to be strategic, it is necessary to plan and implement practices and policies that increase an organization's scope of skills and capabilities aligned with strategic goals (Borges \& Michalisin, 2009; Ulrich, 1998). Strategic human resource management also contributes to the achievement of sustainable competitive advantage through the formation of top management teams (Rothenberg, Hull, \& Tang, 2017), since it helps to create specific competencies (Walls et al., 2011), changes attitudes and behaviors, fosters innovation (Parkes \& Borland, 2012), and impacts performance (Barney \& Wright, 1998; Walls et al., 2011).

Huselid, Jackson, and Schuler (1997) identified that strategic HR management is directly related to company performance in a sample of 293 companies in the United States. The results of their research indicate that there is a positive relationship between RBV strategies in human resource management and employee productivity, which reflects in terms of a company's cash flow and market value. They also identified that the capacity of human resource professionals affects the effectiveness of HR management activities, in the direction that less qualified professionals lead to less effective management.

Ulrich (1998) suggests that HR management is the leading actor in organizational change management, being responsible for deep transformations in company culture. HR professionals need to identify and implement what is necessary for change, helping employees during the process of setting new patterns of behaviors and activities. As a result, the organization qualifies for employing constant changes because it is able to manage problems, build relationships of trust, and create and execute planned actions. Accordingly, Parkes and Borland (2012) argue that the focus of HR management is to develop leadership, values, culture, change, communication, and organizational development. All these processes support sustainable change strategies by changing employees' patterns of behaviors towards a sustainable perspective, creating environmental sustainable perspectives (Dumont, Shen, \& Deng, 2017).

The human capital approach developed by Ployhart and Moliterno (2011) suggests that human capital is a unique resource, created from the knowledge of individuals, their skills, and other characteristics. The authors have identified that human capital is a key resource significantly related to individual performance.

In Brazil, Brito and Oliveira (2016) have also identified a positive relationship between HR practices and performance. Nonetheless, the result of a meta-analysis conducted in 16 research papers relating HR management and performance from the thirteen top journals in Brazil found a predominance of isolated HR practices. These studies fail to look at HR practices as a whole system. Strategic human resource management is supposed to integrate HR practices towards the achievement of organizational goals. Bianchi, Quishida, and Foroni (2017) emphasize that strategic human resources must incorporate concerns about the importance of leadership and the role of commitment without losing perspective of organizational performance.

Hart (1995) emphasizes the relevance of HR management to encourage individuals to incorporate sustainable practices into a sustainable competitive advantage. By integrating the sustainable practices into the company's routine, green concerns naturally become a part of the organizational routine. In the categories created by Walls, Phan and Berrone (2011) based on NRBV strategies as a source of capabilities required for proactive environmental strategy, two were central: the environmental HR training programs and environmental performance evaluating systems. These findings highlight the importance of HR management for sustainable competitive advantage.

Aragón-Correa and Sharma (2003) and Hart and Sharma (2004) point out the need to develop skills in the field of green technologies. Since this area is characterized by the uncertain knowledge that involves complex dynamics, HR management has to strategically develop knowledge through training and recruiting systems, for example. They need to integrate, build and reconfigure internal and external skills to keep pace with rapid environmental changes. Dubois and Dubois (2012) argue that human resource professionals are the architects of the practices, policies, and systems, since they develop, 
implement, and enhance such practices. HR professionals need to prepare employees to meet environmental strategic goals.

In this study, sustainable competitive advantage can be achieved as result of the alignment of HR practices with NRBV environmental strategies, building organizational sustainability. Thus, a sustainable environment exists when the organization routinely experiences environmental strategies, from its operational practices to its strategic dynamics. This perspective is related to the companies' sustainable capabilities (Chan, 2005; Walls et al., 2011) since HR practices influence the creation of this sustainable culture and the implementation of NRBV strategies.

Several authors analyzed the HR management under the Resource Based View approach. Wright, McMahan, and McWilliams (1994) discussed how human resources can be valuable, rare, inimitable, and non-substitutable as the basis for organizations to achieve sustainable competitive advantage. Buller and McEvory (2016) used the RBV as a foundation to explain how organizations control human capital combined with external forces (environmental and economic) to achieve competitive advantage. The authors add that because HR practices delineate organizational capabilities, group competencies, and individual knowledge, skills, and abilities, they are a powerful tool to improve organizational performance.

Delery and Roumpi (2017) posit that HR management and sustainable competitive advantage are commonly related in the literature by two aspects. The first aspect is the HR practices are viewed as a system, and if well designed by the organization, can easily meet the RBV conditions of valuable, hard to imitate, unique, and ambiguous. The other aspect is that the organizational workforce by itself is viewed as rare, inimitable, and non-substitutable. Therefore, organizations can use human capital as a lever to achieve a sustainable competitive advantage.

1. Valuable HRM: The labor market is quite heterogeneous because each individual contributes in her/his own way as a result of formal education and life experience (Wright, McMahan, \& McWilliams, 1994). This heterogeneity makes duplication difficult. Furthermore, having a qualified labor force is frequently related to the financial value of organizations (Wright et al., 1994). Barney and Wright (1998) posit that two of the great challenges in generating a valuable HR management are reducing costs and increasing revenues. For example, Kronos, which is a company with more than 5,000 employees and provides services in workforce management and human capital management, implemented the open vacation policy. This policy consists of unlimited time off, which means that employees decide for themselves how much time off they need. The company trusts employees to get their jobs done under its open vacation policy because they keep engaged. This policy went into effect in 2016. On average, Kronos' employees took 2.6 days more in 2016 than 2015. In some cases, employees took six weeks of vacation. The interesting point is that highperforming employees felt entitled to take more days off, and millennials were the most enthusiastic about the policy. Ain (2017), the CEO of Kronos, reported that 2016 was the best year ever financially.

2. Rare HRM: The quality of human resources is the result of a combination of skills and abilities that each employee brings to the organization or develops inside the organization. The recruitment process is the first step to building a high-quality labor force. Training and development practices are also employed to help employees acquire knowledge and competencies necessary to perform their activities. Motivating strategies and tools such as feedback and social support are great allies in the process of increasing the quality of human resources because it is consistently related to firm's performance (Van Wingerden, Derks, \& Bakker, 2017). Bakker and Xanthopoulou (2013) give an example of rare HRM in a research about the relationship between job resources and creativity and charismatic leadership behavior in school principals and teachers. As a result, they found that a link exists between job resources and creativity. They suggest that job resources can facilitate employees' sense of self-efficacy and resiliency, which foster work engagement. Engaged school principals are considered by the teachers to be charismatic and creative. It shows that job resources as practices focused on the individuals' behavior can influence their skills and abilities, creating complexity and rareness. 
3. Inimitable HRM: Human capital is by its nature hard to imitate. For competitors who are trying to imitate this competitive advantage, it is initially necessary to identify exactly what are the contributions of employees' qualifications to organizational performance. After identifying this relationship, it is necessary to reproduce the same thing in another organizational context (Wright $e t$ al. 1994). Machinery or technology imitation is more likely to occur because they are tangible resources. However, human resources are usually an embedded, complex combination of individual characteristics, such as cognition, behavior, and emotions (Pardo Del Val \& Fuentes, 2003). In addition, Saá-Pérez and García-Falcón (2002) argue that the relationship between HR management and performance is directly related to the organizational ability to influence employees' behavior. Therefore, perfect imitation is unlikely to occur regarding human resources, since it encompasses environmental contexts. Moreover, human interactions generate social complexity that is another limitation to imitation (Barney \& Wright, 1998; Rothenberg et al., 2017; Wright et al., 1994).

4. Non-substitutable HRM: Some employees' capabilities, like learning and adapting, are strategically enforced and encouraged by HR management policies and practices, which make them a non-replaceable resource (Wright et al., 1994). Human resources are able to learn, develop, and innovate in the face of new technologies and needs. Organizations explore this type of resource according to their own strategies and abilities to do so. Having the resources without knowing how to exploit them is not enough. Barney and Wright (1998) argue that companies need to develop systems and practices that allow the use of employees' full potential at individual and team levels to be a source of competitive advantage. Since the usage of employees' capabilities highly depends on how organizations manage the HR systems, HR management as a whole is hard to substitute due to its context related nature.

Therefore, HR management gathers the RBV factors because the quality of human capital within organizational context is hard to imitate, valuable, rare, and non-substitutable. Saridakis, Lai, and Cooper (2017) add that highly developed, well designed, and sophisticated HR practices are more likely to be a source of competitive advantage as they meet RBV criteria. In the environmental context, human resource management may also play a strategic role in the relationship between the employment of environmental strategies and the achievement of sustainable competitive advantage. Since HR practices build a basis for employees to develop skills, knowledge, and abilities, they can be employed as an organizational competency towards environmental strategies creating value to the organization, stakeholders, consumers, and society.

\section{Theoretical framework}

The Natural RBV strategies-pollution prevention, product stewardship, and sustainable development - can lead organizations towards the achievement of sustainable competitive advantage (Hart, 1995; Hart \& Dowell, 2011). In this study, based on the literature review we propose that human resources management plays a strategic role in the NRBV theory when HRM embeds environmental concerns in its practices and policies. Figure 1 illustrates that sustainable competitive advantage can be achieved when organizations incorporate environmental concerns allied with green NRBV strategies in their HR management practices. 


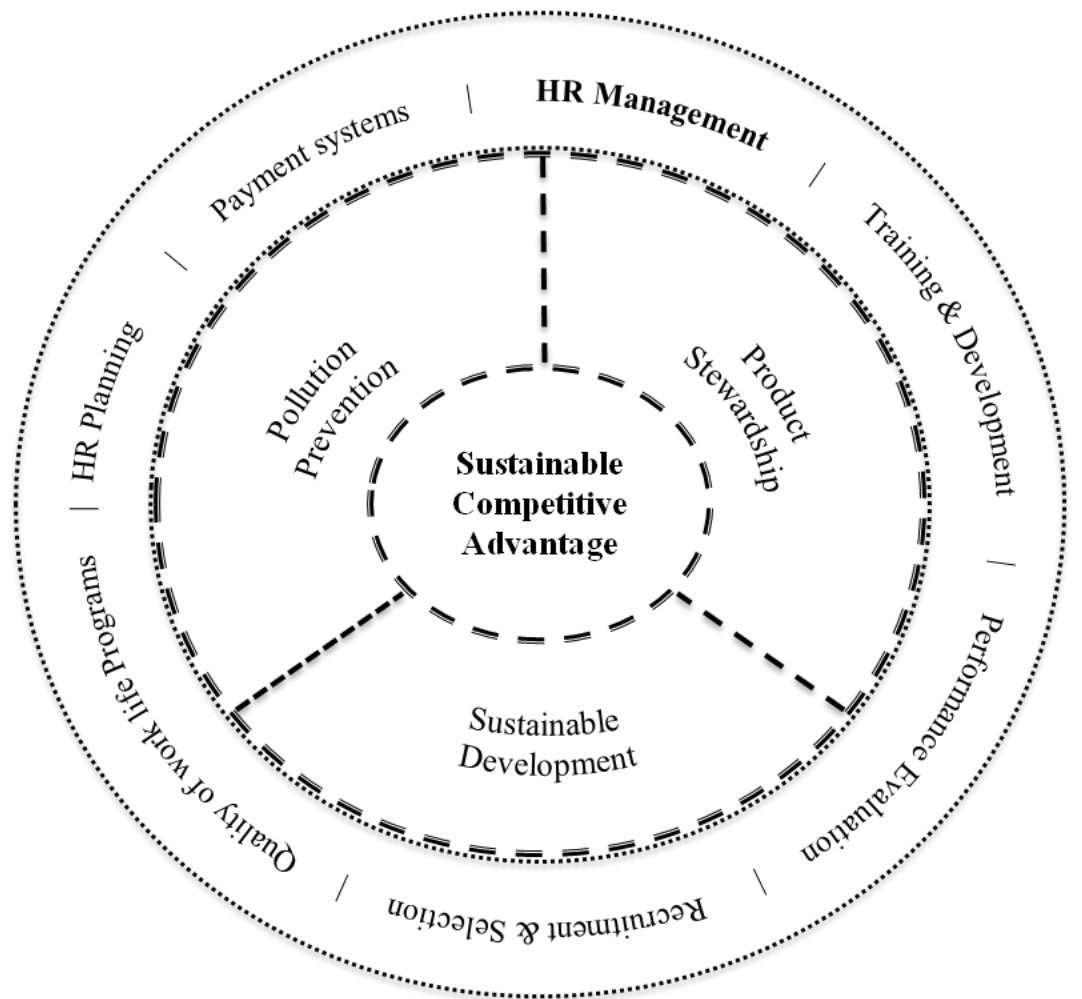

Figure 1. Framework of HR Management in the Natural-RBV Strategies Source: Designed by the authors.

Pollution can be reduced by controlling emissions through pollution control equipment. Another way to reduce pollution is working on prevention, like regularly running cleaning procedures, replacing outdated materials, recycling, and cutting waste. The pollution prevention strategy requires employee involvement to continuously reduce pollutant emissions (Castro, Mello, \& Pinto, 2012; Jeon, Dant, \& Baker, 2016). Organizations can mitigate pollution by not only investing in technologies for the production process but also by employing total quality management tools. It is possible to increase productivity and efficiency and reduce the cost of essential materials by minimizing waste. This strategy can create advantages over competitors at the same time as organizations optimize the usage of resources (Hart, 1995; Hart \& Dowell, 2011).

HR management focused on the pollution prevention strategy has the potential to create competitive advantage in economic, environmental, and social sustainability dimensions. Economically because HR management can promote, hire, and reward employees based on financial outcomes related to the adoption of environmental strategies (Azapagic, 2003). Environmental sustainability because HR management can adopt simple green practices that directly affect the generation of waste and pollution, like terminating the use of plastic or any disposable materials. Finally, HR management can improve social sustainability because it presupposes the participation and direct involvement of the employees in environmental strategies (Borim-de-Souza et al., 2015). Pollution prevention strategy alone does not lead to organizational sustainability, but it is an initial effort which helps to change organizational culture and create sustainability by employing environmental oriented HR practices.

Product stewardship expands the scope of pollution prevention because it refers to environmental concerns in the production design and processes, by analyzing product lifecycle and the value chain. This strategy offers organizations a differential in the field of sustainable products. For example, it is possible to combine strategies to create sustainable competitive advantage offering open spaces for stakeholders - environmentalists, community leaders, employees, governments, etc. - to participate in planning, development, or redesign production processes (Hart, 1995; Hart \& Dowell, 2011). Strategic decisions regarding the ecological design of products, the replacement of material, or the implementation of green logistics increase organizational performance and operational footprint (Fraj, Martínez, \& Matute, 2013). 
HR management can embrace product stewardship strategy into its practices by encouraging employees to create value for products and services. Stakeholder participation in specific strategies can generate alternative solutions for some demands that were first unmet. Environmental sustainability is contemplated when the whole process is understood, which includes employees from all hierarchical levels. Organizations that implement the product stewardship strategy with the support of HR management policies and practices create a green-oriented environment, which facilitates the path toward sustainable competitive advantage.

Sustainable development from the perspective of the NRBV focuses on reducing the negative relationship between economic activity and the environment in developing countries. However, these countries are seen as the market for the future and they still hold the potential to offer a competitive advantage for many multinationals. Companies competing in these markets have the opportunity to envision sustainable technologies and products that do not yet exist, leading to a sustainable competitive advantage. In order to do so, long-term investment and commitment to economic and social development are necessary (Hart, 1995; Hart \& Dowell, 2011).

Companies from the Southern Hemisphere can also support sustainable development as they exploit their own resources by engaging in social activities to stimulate local development. These companies foster a healthy cycle of exploiting just enough resources for their growth and development; their growth and development support local economic, political and social development, which help local communities and organizations to continue operating (Hart, 1995). The sustainable development strategy also contemplates the dimensions of organizational sustainability. Environmental sustainability is also concerned with the excessive exploitation of the natural resources of the Southern Hemisphere and social sustainability is concerned with the imbalance in social development between regions.

Organizations use HR management policies and practices to promote sustainable development. Usually, companies start from their neighborhood, because these communities are the first to be impacted by companies' operations. HR management may include the development of solutions to improve populations' macro or micro living conditions in employees' performance evaluations. Such actions help to create an organizational culture which values sustainable development. Thus, HR management that embraces sustainable development values and goals in its policies and practices help organizations to achieve sustainable competitive advantage.

The HR system must be able to align HR practices with sustainable goals in order to meet VRIO characteristics (Barney \& Mackey, 2016; Buller \& McEvoy, 2016). The HR practices such as training and development, performance evaluation, recruitment and selection, quality of work-life programs, planning, and payment, can be designed to change employees' behavior and organizational culture by including sustainable values (Brito \& Oliveira, 2016; Buller \& McEvoy, 2016).

Wagner (2013) analyzed how the payment system contributes to environmental strategies in 36 Germany companies. He included recruitment and retention practices and employee satisfaction as potential predictors of the effectiveness of the payment system implementation. The results indicate that payment and benefits are associated with both variables, but the association is greater with employee satisfaction. It draws attention to the need for integration between sustainable strategies and quality of work-life programs like health and safety. The results also suggest that environmental management systems get more complex as the economic benefits raise. Therefore, pollution prevention becomes more effective and individuals seek to contribute to the production process as reward and benefits systems become intrinsically related to the product management strategy.

HR management may also train and compensate employees to find ways to reduce waste generation and pollutant emissions (Cohen, Taylor, \& Muller-Camen, 2012). Langwell and Heaton (2016) for example, studied the HR practices of six companies in the state of Iowa in the USA responsible for implementing the Petal Project and Sustainability Circles in small and medium enterprises. This project contemplates five different areas: staff training, energy conservation, pollution prevention, waste reduction, and water conservation. As a result, they found that training is fundamental for employees to understand the importance of sustainability, innovation, and the development of 
sustainable goals. They emphasize that the Finley Hospital annually assesses their environmental policy training. Employees need to pass the training evaluation to remain in the organization. The authors also noticed the existence of a variety of incentives to encourage sustainable behaviors, but it is the recruiting system that makes the first move by admitting individuals who exhibit environmental concerns.

Alt and Spitzeck (2016) conducted a study of 170 companies to investigate which factors influence the organizational citizenship behaviors (OCB) towards environmental concerns. They concluded that the level of employees' involvement in environmental OCB is translated into environmental performance, and this relationship is strengthened if there is a shared vision. The authors suggest that managers who want to improve environmental performance should promote employees' involvement in environmental OCB and offer a shared vision. Therefore, leadership training, incentive programs, and cultural change are HR actions that contribute to pollution prevention, product management, and sustainable development, as OCB refer to social behaviors that improve the effectiveness of environmental management in organizations.

In another example, Aboelmaged (2018) presents an analysis of sustainable manufacturing practices (SMP) in 238 small and medium enterprises in Egypt. One of the results suggests that the environmental pressures of consumers, competitors, and media influence SMP significantly. He also found a significant impact on employee engagement and management support on the effectiveness of sustainability programs. In this sense, HR overcomes the physical limitations of the company and acts globally (Ulrich, Allen, Brockbank, Younger, \& Nyman, 2011) to develop a broader sustainable behavior. From this perspective, HR would act as a predictor of organizational sustainability.

Communication and engagement have been pointed out as a powerful tool for HR management because of the necessity of internal and external alignment to create sustainable awareness. For example, at Premier Bank, all employees are asked to volunteer in the local community, and in the Dubuque Bank and Trust there are programs that encourage donations of time and another resources to nonprofit organizations (Langwell \& Heaton, 2016). In this way, the organizations generate alignment between employees and the company's sustainable practices. It is another way HR management reinforces sustainable values between stakeholders and shareholders (Ulrich et al., 2011).

These examples show that environmental sustainable goals can be inserted in performance appraisal systems and training programs assessment; benefits can be targeted to increase individuals' engagement in sustainable actions; recruitment and selection practice can focus on the personorganization fit of sustainable values; and, quality of work-life programs can encourage employees to engage in environmental citizenship behaviors. The development of an effective communication system aligned with sustainable strategies helps organizations to connect their image to green concerns. Cohen, Taylor, and Muller-Camen (2012) argue that initially HR managers must understand and adopt the practices developed by leading players. Then they must aim for High-Performance Work Practice (HPWPs). However, it is the contextual reality of each organization that will dictate the best practices to be adopted in terms of sustainable competitive advantage (Braney \& Mackey, 2016).

In sum, the proposed framework suggests that HR management leverages the Natural RBV strategies towards the achievement of sustainable competitive advantage. The HR management must include values and goals in its policies and practices that enforce the pollution prevention, product stewardship, and sustainable development strategies. Human resources practices are a powerful tool that organizations frequently fail to consider when designing key strategies. This framework draws attention to the importance of HR management by providing a systemic view of NRBV strategies.

\section{Discussion and Conclusions}

Organizational sustainability is a complex phenomenon and there is still a lot to be developed and understood in the literature (Buller \& McEvory, 2016). Regarding business administration, 
organizational sustainability can be a powerful option for companies to achieve sustainable competitive advantage (Dubois \& Dubois, 2012). Companies that focus on the environmental, economic, and social dimension of organizational sustainability are successful in meeting legal requirements, managing processes and routines, and using natural resources effectively (Borim-de-Souza et al., 2015). Therefore, the objective of this essay is to present a theoretical framework by analyzing the role of human resource management in helping organizations achieve sustainable competitive advantage, through the natural resource-based view perspective.

Usually, the environmental dimension is pointed out as the first step towards sustainability because it is easier to implement. Some initiatives involve recycling, using energy efficiently, and reducing waste. However, these examples cannot be interpreted as isolated initiatives, rather they are the beginning of a broad process of cultural change to environmental sustainability (Marrewijk \& Werre, 2003). Economic sustainability involves a dynamic process of wealth generation for stakeholders, so organizations act responsibly with society, in terms of offering sustainable products, services, paying fair salaries, and so forth (Azapagic, 2003). Stakeholder integration is the major idea behind the social sustainability dimension. Organizations promote a space for participation which allows different actors - employees, suppliers, local communities, global consumers, etc. - to offer their perspective and build key strategies together (Borim-de-Souza et al., 2015).

From the organizational sustainability perspective, which includes the environmental, financial, and social dimensions, the Natural RBV strategies are presented as key capabilities with drive organizations towards sustainable competitive advantage. However, the major contribution of this study is adding the HR management to this equation by presenting an integrative framework. The basic assumption in this framework is that HR management can foster the implementation of NRBV strategies, which, in order to be successful, require changes in employees' values, behaviors, and attitudes. Therefore, this study intends to contribute to the literature as it fills the gap presented by Chan (2005) on the lack of research about the involvement of employees in the adoption of green strategies. Moreover, it addresses the call of Delery and Roumpi (2017) for alternative paths to achieve a sustainable competitive advantage through HR management.

Future research may empirically test the proposed model by developing hypotheses and measures for the variables. Researchers can also add value to the literature by testing the proposed framework in the Brazilian context. This will broaden the comprehension of the Southern Hemisphere and provide knowledge about Brazilian reality regarding HR management and organizational sustainability. To the NRBV literature, the results might expand the scope of sustainable strategies, and the social and environmental responsibility of organizations in developing countries. For practitioners and managers, this study can present alternatives to stimulate the development of practices aligned with environmental strategies, in order to directly influence companies' strategic results (Borges \& Michalisin, 2009).

Future research may also investigate if HR management acts as a moderator in the relationship between NRBV strategies and sustainable competitive advantage. HR management can be a catalyst to SCA if there is an alignment between organizational culture and NRBV strategies. On the other hand, HR management can act as a barrier to the achievement of SCA if employees do not understand the importance of pollution prevention, product stewardship, and sustainable development strategies.

The major limitation of this study is the use of the RBV approach as a foundation to the integrative framework proposed. The RBV approach has been under severe critique since due to the lack of consistent measures to investigate the relationship between RBV and sustainable competitive advantage (Shaw, Park, \& Kim, 2013). Kaufman (2015) identified four critical gaps in RBV theory and practice: (a) no rules for implication regarding the causality and stability of HR practices on firm performance; (b) lack of consistent definitions and measurements of competitive advantage and HRM as dependent variable; (c) lack of HRM marginal decision rules on RBV strategies; and, (d) the implications for employee relations is not clear, as to how RBV enhances performance.

On the other hand, Kaufman (2015) remembers that theoretical advancement depends on criticism. For example, Shaw, Park, and Kim (2013) inverted the positive perspective and investigated 
how human capital losses such as turnover negatively affect performance. Their research findings indicate that in organizations with high HRM investments, performance decreases significantly with human capital losses, but in organizations, with low HRM investments, such relationship is weaker. In a broader perspective, Madhok (2002) suggests an alignment between RBV, transaction costs theory, and institutional theory. The author proposes that there is interdependence between important organizational resources, transactions, and governance structure.

The more companies focus on sustainability, employing sustainable development strategies, such as those proposed by the NRBV, the more society can envision a balanced world. The company positions itself as a part of a social complex system positioning environmental sustainability as a key value. Companies that carry out sustainable strategies are aware that responsible exploration generates a cycle of social development as it mitigates footprint (Sato \& Pedrozo, 2012; Sehnem, Pavão, Rossetto, \& Leonardi, 2012; Silva \& Balbino, 2013).

HR management processes are fundamental resource organizations have to develop environmental sustainable. For example, Colbert and Kurucz (2007) identified key HR processes for sustainability, which are: change management, HR strategic planning, talent management, and training and development. The results of Colbert and Kurucz (2007) research indicate that HR management's major challenges are: aligning the concept of sustainability with HR practices and aligning organizational leadership to highlight values that support the development of strategic capabilities. Studies such as Vidal-Salazar, Cardón-Pozo, and Ferrón-Vilchez (2012), carried out with 252 tourism companies, demonstrate how HR management develops proactive environmental strategies through environmental training and organizational learning. Unfortunately, no study was found relating the propositions presented here and the Brazilian context.

A possible way to empirically test the proposed model would be the analysis of environmental practices carried out by large companies. These companies have greater potential to fulfill NRBV strategies and invest in HR management. The goal would be to identify the effect of this on return on investment (ROI). Another way would be to study a single company comparing its financial results before and after the incorporation of sustainable strategies leveraged by HR management. Therefore, the implementation of NRBV strategies along with human resource management intervention can influence performance and be an important part of sustainable competitive advantage.

\section{References}

Aboelmaged, M. (2018). The drivers of sustainable manufacturing practices in Egyptian SMEs and their impact on competitive capabilities: A PLS-SEM model. Journal of Cleaner Production, 175, 207221. http://dx.doi.org/10.1016/j.jclepro.2017.12.053

Ain, A. (2017, November/December). The CEO of kronos on launching an unlimited vacation policy. Harvard Business Review, 37-42. Retrieved January 3, 2018, from https://hbr.org/2017/11/theceo-of-kronos-on-launching-an-unlimited-vacation-policy

Alt, E., \& Spitzeck, H. (2016). Improving environmental performance through unit-level organizational citizenship behaviors for the environment: A capability perspective. Journal of Environmental Management, 182, 48-58. http://dx.doi.org/10.1016/j.jenvman.2016.07.034

Aragón-Correa, J. A., \& Sharma, S. (2003). A contingent resourced-based view of proactive corporate environmental strategy. Academy of Management Review, 28(1), 71-88. http://dx.doi.org/10.5465/AMR.2003.8925233

Azapagic, A. (2003). Systems approach to corporate sustainability: A general management framework. Process Safety and Environmental Protection, 81(5), 303-316. http://dx.doi.org/10.1205/095758203770224342 
Bakker, A. B., \& Xanthopoulou, D. (2013). Creativity and charisma among female leaders: The role of resources and work engagement. The International Journal of Human Resource Management, 24(14), 2760-2779. http://dx.doi.org/10.1080/09585192.2012.751438

Barney, J. B. (1991) Firm resources and sustained competitive advantage. Journal of Management, 17(1), 99-120. http://dx.doi.org/10.1177/014920639101700108

Barney, J. B., \& Mackey, A. (2016). Text and metatext in the resource-based view. Human Resource Management Journal, 26(4), 369-378. http://dx.doi.org/10.1111/1748-8583.12123

Barney, J. B., \& Wright, P. M. (1998). On becoming a strategic partner: the role of human resources in gaining competitive advantage. Human Resource Management, 37(1), 31-46. http://dx.doi.org/10.1002/(SICI)1099-050X(199821)37:1<31::AID-HRM4>3.0.CO;2-W

Bianchi, E. M. P. G., Quishida, A., \& Foroni, P. G. (2017). Atuação do líder na gestão estratégica de pessoas: Reflexões, lacunas e oportunidades. Revista de Administração Contemporânea, 21(1), 41-61. Recuperado de http://www.scielo.br/pdf/rac/v21n1/1415-6555-rac-21-01-00041.pdf. http://dx.doi.org/10.1590/1982-7849rac2017150280

Borges, R. S. G., \& Michalisin, M. (2009). Environmental human resource management practices and business sustainability. Proceedings of the Annual Meeting of the Decision Science Institute, New Orleans, USA, 40.

Borim-de-Souza, R., Balbinot, Z., Travis, E. F., Munck, L., \& Takahashi, A. R. W. (2015). Sustainable development and sustainability as study objects for comparative management theory: proposing styles of reasoning for an unknown metropole. Cross Cultural Management: An International Journal, 22(2), 2-20. http://dx.doi.org/10.1108/CCM-02-2013-0027

Brito, R. P., \& Oliveira, L. B. (2016). The relationship between human resource management and organizational performance. Brazilian Business Review, 13(3), 90-110. http://dx.doi.org/10.15728/bbr.2016.13.3.5

Buller, P. F., \& McEvoy, G. M. (2016). A model for implementing a sustainable strategy through HRM practices. Business and Society Review, 121(4), 465-496. http://dx.doi.org/10.1111/basr.12099

Câmara dos Deputados. (2015, novembro 17). Política de incentivo à produção do café de qualidade é aprovada em Comissão. Recuperado em 29 novembro, 2017, de http://www2.camara.leg.br/camaranoticias/noticias/agropecuaria/500138-politica-de-incentivoa-producao-de-cafe-de-qualidade-e-aprovada-em-comissao.html

Câmara dos Deputados. (2016, outubro 11). Projeto institui política de incentivo à produção de borracha. Recuperado em 29 outubro, 2017, de http://www2.camara.leg.br/camaranoticias/noticias/economia/517459-projeto-instituiu-politicade-incentivo-a-producao-da-borracha.html.

Cano, W. (2017). Brasil: Construção e desconstrução do desenvolvimento. Economia e Sociedade, 26(2), 265-302. https://dx.doi.org/10.1590/1982-3533.2017v26n2art1

Castro, V. A., Mello, E., Jr., \& Pinto, R. M. C. (2012). Gestão do conhecimento - GC - como recursos estratégico e fonte de vantagem competitiva sustentável - VCS - na perspectiva resource-based view - RBV. Organizações em Contexto, 8(15), 21-41. http://dx.doi.org/10.15603/19828756/roc.v8n15p21-41 
Chan, R. Y. K. (2005). Does the natural-resource-based view of the firm apply in an emerging economy? A survey of foreign invested enterprises in China. Journal of Management Studies, 42(3), 625672. http://dx.doi.org/10.1111/j.1467-6486.2005.00511.x

Christmann, P. (2000). Effects of "best practices" of environmental management on cost advantage: The role of complementary assets. Academy of Management Journal, 43(4), 663-680. http://dx.doi.org/10.2307/1556360

Cohen, E., Taylor, S., \& Muller-Camen, M. (2012). HR's role in corporate social responsibility and sustainability. Alexandria, VA: SHRM Foundation Executive Briefing.

Colbert, B. A., \& Kurucz, E. C. (2007). Three conceptions of triple bottom line business sustainability and the role for HRM. Human Resource Planning, 30(1), 21-29. Retrieved October 29, 2017, from http://www.stakeholderresearch.com/documents/sra-three-conceptions.pdf

Delery, J. E., \& Roumpi, D. (2017). Strategic human resource management, human capital and competitive advantage: Is the field going in circles? Human Resource Management Journal, 27(1), 1-21. http://dx.doi.org/ 10.1111/1748-8583.12137

Dias, R. (2015). Sustentabilidade: Origem e fundamentos; educação e governança global; modelo de desenvolvimento. São Paulo: Atlas.

Dubois, C. L. Z., \& Dubois, D. A. (2012). Strategic HRM as social design for environmental sustainability in organization. Human Resource Management, 51(6), 799-826. http://dx.doi.org/10.1002/hrm.21504

Dumont, J., Shen, J., \& Deng, X. (2017). Effects of green hrm practices on employee workplace green behavior: The role of psychological green climate and employee green values. Human Resource Management, 56(4), 613-627. http://dx.doi.org/10.1002/hrm.21792

Elkington, J. (1994). Towards the sustainable corporation: Win-win-win business strategies for sustainable development. California Management Review, 36(3), 90-100. http://dx.doi.org/10.2307/41165746

Fraj, E., Martínez, E., \& Matute, J. (2013). Green marketing in B2B organisations: an empirical analysis from the natural-resource-based view of the firm. The Journal of Business \& Industrial Marketing, 28(5), 396-410. http://dx.doi.org/10.1108/08858621311330245

Gabriele, P. D., Treinta, F. T., Farias, J. R., Filho, Souza, M. C., Tschaffon, P. B., \& Brantes, S. R. (2012). Sustentabilidade e vantagem competitiva estratégica: um estudo exploratório e bibliométrico. Revista Produção Online, 12(3), 729-755. http://dx.doi.org/10.14488/16761901.v12i3.975

Golicic, S. L., \& Smith, C. D. (2013). A meta-analysis of environmentally sustainable supply chain management practices and firm performance. Journal of Supply Chain Management, 49(2), 7895. http://dx.doi.org/10.1111/jscm.12006

Hart, S. L. (1995). A natural-resource-based view of the firm. Academy of Management Review, 20(4), 986-1014. http://dx.doi.org/10.2307/258963

Hart, S. L., \& Dowell, G. (2011). A natural-resource-based view of the firm: fifteen years after. Journal of Management, 37(5), 1464-1479. http://dx.doi.org/10.1177/0149206310390219

Hart, S. L., \& Sharma, S. (2004). Engaging fringe stakeholders for competitive imagination. Academy of Management Perspectives, 18(1), 7-18. http://dx.doi.org/10.5465/AME.2004.12691227 
Huselid, M. A., Jackson, S. E., \& Schuler, R. S. (1997). Technical and strategic human resource management effectiveness as determinants of firm performance. Academy of Management Journal, 40(1),171-188. http://dx.doi.org/10.2307/257025

Jeon, H. J. (J.), Dant, R. P., \& Baker, B. L. (2016). A knowledge-based explanation of franchise system resources and performance. Journal of Marketing Channels, 23(3), 97-113. http://dx.doi.org/10.1080/1046669X.2016.1186470

Kaufman, B. E. (2015). The RBV theory foundation of strategic HRM: Critical flaws, problems for research and practice, and an alternative economics paradigm. Human Resource Management Journal, 25(4), 516-540. http://dx.doi.org/10.1111/1748-8583.12085.

Langwell, C., \& Heaton, D. (2016). Using human resource activities to implement sustainability in SMEs. Journal of Small Business and Enterprise Development, 23(3), 652-670. http://dx.doi.org/10.1108/JSBED-07-2015-0096

Lélé, S. M. (1991). Sustainable development: A critical review. World Development, 19(6), 607-621. http://dx.doi.org/10.1016/0305-750X(91)90197-P

Lima, T. C. S., \& Mioto, R. C. T. (2007). Procedimentos metodológicos na construção do conhecimento científico: A pesquisa bibliográfica [Edição Especial]. Revista Katálysis, 10, 37-45. http://dx.doi.org/10.1590/S1414-49802007000300004

Madhok, A. (2002). Reassessing the fundamentals and beyond: Ronald Coase, the transaction cost and resource-based theories of the firm and the institutional structure of production. Strategic Management Journal, 23(6), 535-550. http://dx.doi.org/10.1002/smj.247

Marrewijk, M. van, \& Werre, M. J. (2003). Multiple levels of corporate sustainability. Journal of Business Ethics, 44(2/3), 107-119. http://dx.doi.org/10.1023/A:1023383229086

Mebratu, D. (1998). Sustainability and sustainable development: Historical and conceptual review. Environmental Impact Assessment Review, 18(6), 493-520. http://dx.doi.org/10.1016/S01959255(98)00019-5

Menguc, B., \& Ozanne, L. K. (2005). Challenges of the "green imperative": A natural resource-based approach to the environment orientation-business performance relationship. Journal of Business Research, 58(4), 430-438. http://dx.doi.org/10.1016/j.jbusres.2003.09.002

Michalisin, M. D., \& Stinchfield, B. T. (2010). Climate change strategies and firm performance: An empirical investigation of the natural-resource-based view of the firm. Journal of Business Strategies, 27(2), 123-149. Retrieved October 28, 2017, from https://www.questia.com/read/1G1247443169/climate-change-strategies-and-firm-performance-an

Munck, L., \& Borim-de-Souza, R. (2011). O ecletismo do paradigma da sustentabilidade: Construção e análise a partir dos estudos organizacionais. Revista de Ciências da Administração, 13(29), 202242. http://dx.doi.org/10.5007/2175-8077.2011v13n29p202

Munck, L., Bansi, A. C., \& Galleli, B. (2016). Sustentabilidade em contexto organizacional: Uma análise comparativa de modelos que propõem trajetórias para sua gestão. Revista de Ciências da Administração, 18(44), 91-110. http://dx.doi.org/10.5007/2175-8077.2016v18n44p91

Pardo Del Val, M., \& Fuentes, C. M. (2003). Resistance to change: A literature review and empirical study. Management Decision, 41(2), 148-155. Retrieved October 27, 2017, from http://www.emeraldinsight.com/0025-1747.htm

Parkes, C., \& Borland, H. (2012). Strategic HRM: Transforming its responsibilities toward ecological sustainability - the greatest global challenge facing organizations. Thunderbird International Business Review, 54(6), 811-824. http://dx.doi.org/10.1002/tie.21505 
Pee, L. G., \& Kankanhalli, A. (2015). Interactions among factors influencing knowledge management in public-sector organizations: a resource-based view. Government Information Quarterly, 33(1), 188-199. http://dx.doi.org/10.1016/j.giq.2015.06.002

Ployhart, R. E., \& Moliterno, T. P. (2011). Emergence of the human capital resource: A multilevel model. Academy of Management Review, 36(1), 127-150. http://dx.doi.org/10.5465/amr.2009.0318

Rothenberg, S., Hull, C. E., \& Tang, Z. (2017). The impact of human resource management on corporate social performance strengths and concerns. Business \& Society, 56(3), 391-418. http://dx.doi.org/10.1177/0007650315586594

Saá-Pérez, P., \& García-Falcón, J. M. (2002). A resource-based view of human resource management and organizational capabilities development. International Journal of Human Resource Management, 13(1), 123-140. http://dx.doi.org/10.1080/09585190110092848

Saridakis, G., Lai, Y., \& Cooper, G. L. (2017). Exploring the relationship between HRM and firm performance: A meta-analysis of longitudinal studies. Human Resource Management Review, 27(1), 87-96. http://dx.doi.org/10.1016/j.hrmr.2016.09.005

Sartori, S., Latrônico, F., \& Campos, L. M. S. (2014). Sustentabilidade e desenvolvimento sustentável: Uma taxonomia no campo da literatura. Ambiente \& Sociedade, 17(1), 1-22. Recuperado de http://www.scielo.br/scielo.php?script=sci_arttext\&pid=S1414-

$753 X 2014000100002 \& \operatorname{lng}=$ pt\&nrm=iso

Sato, S. A. S., \& Pedrozo, E. A. (2012). Os recursos naturais amazônicos: De uma competitividade sustentável para uma sustentabilidade competitiva. Revista de Administração e Negócios da Amazônia, 4(3), 270-290. Recuperado em 29 outubro, 2017, de http://www.periodicos.unir.br/index.php/rara/article/view/576/627

Sehnem, S., Pavão, Y. M. P., Rossetto, A. M., \& Leonardi, V. A. (2012). Recursos organizacionais em frigoríficos e sua relação com a implantação de estratégias voltadas à sustentabilidade ambiental: O caso do Grupo Marfrig Alimentos S.A. Revista Brasileira de Gestão de Negócios, 14(43), $193-$ 215. http://dx.doi.org/10.7819/rbgn.v14i43.978

Shaw, J. D., Park, T. Y., \& Kim, E. (2013). A resource-based perspective on human capital losses, RHM investments, and organizational performance. Strategic Management Journal, 34(5), 572-589. http://dx.doi.org/10.1002/smj.2025

Shi, V. G., Koh, L., Baldwin, J., \& Cucchiella, F. (2012). Natural resource based green supply chain management. Supply Chain Management: An International Journal, 17(1), 54-67. http://dx.doi.org/10.1108/13598541211212203

Silva, M. E., \& Balbino, D. P. (2013). Criando vantagem competitiva sustentável: A responsabilidade socioambiental empresarial à luz da visão baseada em recursos. Revista Ibero Americana de Estratégia, 12(1), 29-53. http://dx.doi.org/10.5585/riae.v12i1.1805

Ulrich, D. (1998). Os campeões de recursos humanos (7a ed.). São Paulo: Futura.

Ulrich, D., Allen, J., Brockbank, W., Younger, J., \& Nyman, M. (2011). A transformação do RH: Construindo os recursos humanos de fora para dentro. (Fontoura, H., Trad.). Porto Alegre: Bookman.

United Nations Framework Convention on Climate Change. (2014). Kyoto protocol. Retrieved October 27, 2017, from: http://unfccc.int/kyoto_protocol/items/2830.php 
Van Wingerden, J., Derks, D., \& Bakker, A. B. (2017). The impact of personal resources and job crafting interventions on work engagement and performance. Human Resource Management, 56(1), 5167. http://dx.doi.org/10.1002/hrm.21758

Vidal-Salazar, M. D., Cordón-Pozo, E., \& Ferrón-Vilchez, V. (2012). Human resource management and developing proactive environmental strategies: The influence of environmental training and organizational learning. Human Resource Management, 51(6), 905-934. http://dx.doi.org/10.1002/hrm.21507

Wagner, M. (2013). 'Green' human resource benefits: Do they matter as determinants as environmental management system implementations? Journal of Business Ethics, 114(3), 443-456. http://dx.doi.org/10.1007/s10551-012-1356-9

Walls, J. L., Phan, P. H., \& Berrone, P. (2011). Measuring environmental strategy: Construct development, reliability, and validity. Business \& Society, 50(1), 71-115. http://dx.doi.org/10.1177/0007650310394427

Willerding, I. A. V., Silveira, A. C. M., Berchin, I. I., Lapolli, E. M., \& Guerra, J. B. S. O. A. (2016). Strategic management for sustainable development and the organizational aesthetic perspective. Revista Eletrônica de Estratégia \& Negócios, 9(2), 134-166. Recuperado de http://www.portaldeperiodicos.unisul.br/index.php/EeN/article/download/3677/pdf. http://dx.doi.org/10.19177/reen.v9e22016134-165

World Commission on Environmental and Development. (1987). Our common future. New York: Oxford University Press.

Wright, P. M., McMahan, G. C., \& McWilliams, A. (1994). Human resource and sustained competitive advantage: A resource-based perspective. International Journal of Human Resource Management, 5(2), 301-326. http://dx.doi.org/10.1080/09585199400000020

\section{Authors' Profiles}

\section{Lívia Almada}

Rua José Lourenço Kelmer, s/n, 36036-900, Juiz de Fora, MG, Brasil. E-mail address: livia.almada@ufjf.edu.br; livia.almada@facc.ufjf.br. https://orcid.org/0000-0001-9795-8378

Renata Borges

Av. Antonio Carlos, 6627, Edifício FACE, 31270-901, Belo Horizonte, MG, Brasil. E-mail address: renatasg@ face.ufmg.br; renata.guimaraes.borges@gmail.com. https://orcid.org/0000-0001-8116-3327 